\section{Brain Injury Awareness Month - March 2019}

Brain Injury Awareness Month, observed each March, was established 3 decades ago to educate the public about the incidence of brain injury and the needs of persons with brain injuries and their families (1). Caused by a bump, blow, or jolt to the head, or penetrating head injury, a traumatic brain injury (TBI) can lead to short- or long-term changes affecting thinking, sensation, language, or emotion.

A report in this issue of $M M W R$ found that during 2010-2016, nearly 2 million children had a TBI-related emergency department visit because of sports- and recreation-related activities (2). TBIs associated with football, bicycling, playground activities, basketball, and soccer contributed to the majority of these visits (2).

Brain Injury Awareness Month is an opportunity to encourage broader implementation of evidence-based practices to reduce pediatric TBIs and their sequelae. Primary prevention efforts aimed at the leading causes of TBI among children are critical. If a TBI occurs, CDC supports the development of return to activity plans by health care providers, customized to a child's symptoms, as well as linkages to services for children with persistent symptoms to promote positive health outcomes $(3,4)$. Additional information is available at https://www.cdc.gov/traumaticbraininjury.

\section{References}

1. Brain Injury Association of America. March is brain injury awareness month. Vienna, VA: Brain Injury Association of America; 2018. https:/www.biausa.org/public-affairs/public-awareness/news/ march-is-brain-injury-awareness-month

2. Sarmiento K, Thomas K, Daugherty J, et al. Emergency department visits for sports- and recreation-related traumatic brain injuries among children-United States, 2010-2016. MMWR Morb Mortal Wkly Rep 2019;68:237-42.

3. Lumba-Brown A, Yeates KO, Sarmiento K, et al. Centers for Disease Control and Prevention guideline on the diagnosis and management of mild traumatic brain injury among children. JAMA Pediatr 2018;172:e182853. https://doi.org/10.1001/jamapediatrics.2018.2853

4. CDC. Report to Congress: the management of TBI in children. Atlanta, GA: US Department of Health and Human Services, CDC; 2018. https:// www.cdc.gov/traumaticbraininjury/pubs/congress-childrentbi.html

\section{Emergency Department Visits for Sports- and Recreation-Related Traumatic Brain Injuries Among Children — United States, 2010-2016}

Kelly Sarmiento, $\mathrm{MPH}^{1}$; Karen E. Thomas, $\mathrm{MPH}^{2}$; Jill Daugherty, $\mathrm{PhD}^{1}$; Dana Waltzman, $\mathrm{PhD}^{1}$; Juliet K. Haarbauer-Krupa, $\mathrm{PhD}^{1}$; Alexis B. Peterson, $\mathrm{PhD}^{1}$; Tadesse Haileyesus, $\mathrm{MS}^{2}$; Matthew J. Breiding, $\mathrm{PhD}^{1}$

Traumatic brain injuries (TBIs), including concussions, are at the forefront of public concern about athletic injuries sustained by children. Caused by an impact to the head or body, a TBI can lead to emotional, physiologic, and cognitive sequelae in children (1). Physiologic factors (such as a child's developing nervous system and thinner cranial bones) might place children at increased risk for TBI $(2,3)$. A previous study demonstrated that $70 \%$ of emergency department (ED) visits for sports- and recreation-related TBIs (SRR-TBIs) were among children (4). Because surveillance data can help develop prevention efforts, CDC analyzed data from the National Electronic Injury Surveillance System-All Injury Program (NEISS-AIP)*

*https://cpsc.gov/Research--Statistics/NEISS-Injury-Data.

\section{INSIDE}

243 Diagnostic Methods Used to Classify Confirmed and Probable Cases of Spotted Fever Rickettsioses United States, 2010-2015

247 Risk Factors for Congenital Syphilis Transmitted from Mother to Infant — Suzhou, China, 2011-2014

251 Notes from the Field: Botulism Outbreak Associated with Home-Canned Peas — New York City, 2018

253 Notes from the Field: HIV Diagnoses Among Persons Who Inject Drugs — Northeastern Massachusetts, 2015-2018

255 QuickStats

Continuing Education examination available at https://www.cdc.gov/mmwr/cme/conted_info.html\#weekly.

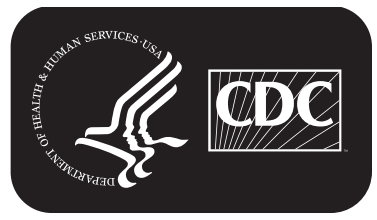

U.S. Department of Health and Human Services Centers for Disease Control and Prevention 